\title{
Un boceto original de Manuel Fontanals
}

\author{
An Original Sketch by Manuel Fontanals
}

\author{
ELISA LOZANO \\ Revista Cuartoscuro
}

RESUMEN: Manuel Fontanals, el arquitecto catalán que llegó a México en 1937 a raíz de la Guerra Civil española, fue el escenógrafo más importante de la llamada "Época de oro" del cine mexicano. Con una brillante trayectoria como escenógrafo teatral, diseñador de vestuario, decorador, ilustrador y diseñador editorial, desarrollada en su país natal y Europa. Fontanals debutó en México como escenógrafo de la película María (1938), de Chano Urueta. A partir de ese momento, y hasta los años setenta, trabajó en más de 200 cintas con directores tan importantes como Emilio Fernández, Roberto Gavaldón y Arturo Ripstein, para quien diseñó los sets de El castillo de la pureza (1972), su último trabajo.

AвSTRACT: Manuel Fontanals was the most prominent stage designer during the Golden Age of Mexican cinema. Following a successful career in Europe as stage, costume and editorial designer, as well as decorator and illustrator, he arrived in Mexico in 1937 after the Spanish Civil War. Fontanals made his debut in Mexico as the set designer for the film María (Chano Urueta, 1938). From that moment and until the seventies, he worked in more than two hundred films with outstanding directors - Emilio Fernández, Roberto Gavaldón - , as well as Arturo Ripstein, for whom he designed the sets of El Castillo de la Pureza (The Castle of Purity) (1972). his last work.

Palabras Clave: Manuel Fontanals, escenografía, cine, boceto.

KEYWORDS: Manuel Fontanals, scenography, cinema, sketch.

RECIBIDO: 15 de enero de 2018 - ACEPTADO: 8 de mayo de 2018 


\section{ELISA LOZANO}

\section{Un boceto original de Manuel Fontanals}

En una producción cinematográfica, el escenógrafo es el responsable de interpretar los espacios y ambientes descritos en el guion y, en acuerdo con el director y el cinefotógrafo, diseña y construye los escenarios $a d$ hoc, según el género, el lugar geográfico y la época en la que se desarrolle la acción de una película. Manuel Fontanals (1893-1972) ejerció esa profesión durante toda su vida, primero en España y después en México; se autodefinía como una persona "mezcla de técnica e impulso creador" (Lozano 2014: 18); tenía razón, la escenografía cinematográfica es un medio de expresión plástica en cuyo diseño se vuelca todo lo aprendido; las vivencias personales y la experiencia en el oficio para manejar de manera adecuada dimensiones, volúmenes, materiales, etcétera, pero, sobre todo, el criterio para seleccionar cada elemento, según su valor expresivo, funcional y psicológico a favor de la historia que se desea contar. Todo esto, aunado a la manera de interpretar un guion y los recursos utilizados para materializarlo, son componentes que distinguen a un escenógrafo de otro.

El primer paso en la escenografía de un proyecto fílmico es hacer dibujos preparatorios de los espacios, los de Fontanals - quien poseía un bagaje artístico excepcional - se caracterizaban por la fuerza y dinamismo del trazo, el notable manejo de la perspectiva y la cuidadosa representación de las fuentes de luz. Entendía el decorado de una película "a la manera de una osamenta, de una estructura que sostiene y vigoriza la acción". No se limitaba a una mera reproducción realista de un espacio, porque si lo hiciera, decía con humor, "un metro —-medida 
de longitud - bastaría a cualquiera para convertirse en escenógrafo" (Fontanals 1946: 18). Afirmaba también que la escenografía para cine había de ser proyectada "como una obra dinámica, en función del movimiento, que, al ir desarrollándose la trama de la película, muestre una composición capaz de sostenerse por su juego de luz y sombras, debido a su propia profundidad" (Fontanals 1946: 18). Así, el decorado debía estar impregnado de la personalidad de quien lo habitaría; así, según la ocasión, la disposición de dicho ambiente sería caótica u ordenada, luminosa u oscura.

Una vez que se fijaba el ambiente psicológico, buscaba los elementos plásticos ad hoc para tales espacios, con todos sus elementos: aru-columnas, volutas, pisos y todo lo que "los viste": cortinas, muebles, lámparas, etcétera. El estilo y la disposición de estos era esencial, ya que cada uno desvelaría algo del mundo interior del personaje que lo ocuparía.

Hay que enfatizar, claro está, que lo anterior estaba subordinado a la meta narrativa y estética propuesta por el director; si daba el visto bueno, los dibujos se enviaban al departamento de construcción, donde un equipo de carpinteros, yeseros y pintores seguían al pie de la letra lo representado por el escenógrafo.

Desafortunadamente, en nuestro país son pocos los materiales originales de este tipo que han sobrevivido hasta nuestros días. No era común que los escenógrafos signaran sus proyectos, ni que incluyeran el título de la película a la que correspondían, tampoco las compañías productoras los conservaran. Por eso, los bocetos y planos que han perdurado son oro molido para el historiador del cine, ya que aportan valiosa información sobre las técnicas de factura de cada periodo.

El boceto que reproducimos aquí, inédito hasta hoy, fue hallado en la colección privada de Leticia Fontanals Subervielle, hija del escenógrafo. Se trata de un apunte a lápiz, sobre una cartulina de formato apaisado, como la pantalla de cine, de $23.5 \mathrm{~cm}$ de largo por $35 \mathrm{~cm}$ de ancho. No está identificado y contiene sólo dos inscripciones: la palabra "Sótano" y una medida: "4.80". 


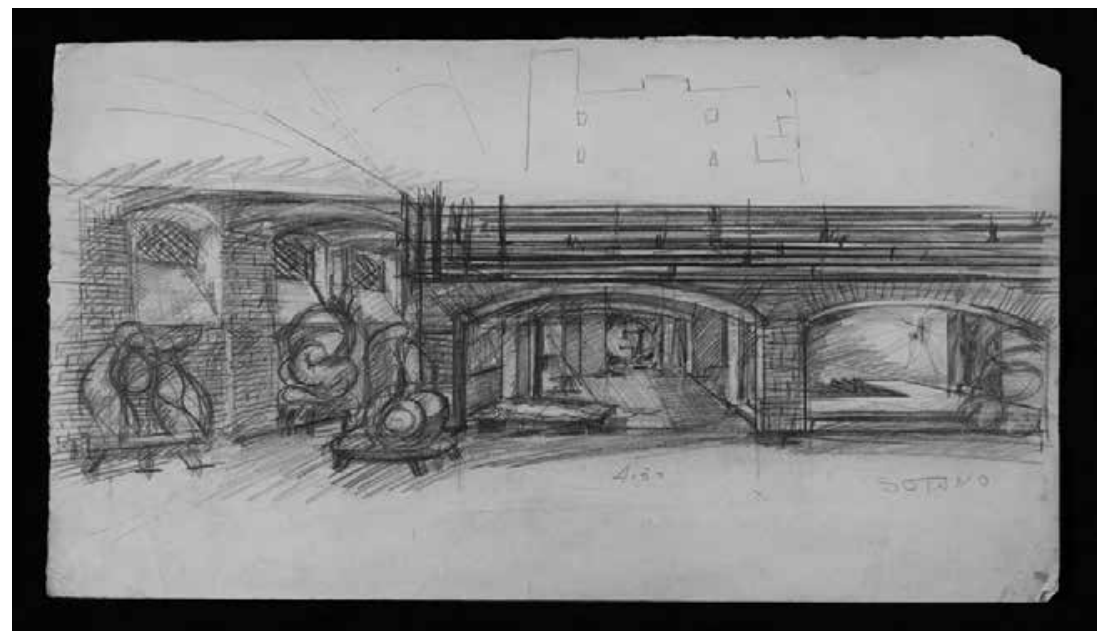

Lo primero que llama la atención es la soltura de la línea y la fuerza del trazo; representa una construcción cerrada de arcos rebajados que semejan dos crujías: en una de ellas, al fondo, se ve una fuente de luz; en la otra, aparece una figura femenina atada a una cama. Del lado izquierdo del cuadro, sobresale un grupo de esculturas y junto a estas, unas troneras enrejadas. Aunque no sabemos a qué película pertenece, por el tipo de espacio, el ambiente lúgubre $\mathrm{y}$, sobre todo, porque la mujer está atada e indefensa, se infiere que podría ser una película de terror o drama, donde es común incorporar este tipo de escenas como recurso dramático.

A nivel metodológico, para determinar a qué cinta corresponde el boceto, fue necesario revisar la filmografía completa del escenógrafo (Peralta 2007), encontramos que en los años sesenta participó en una decena de títulos de terror y drama. Lo siguiente fue revisar fuentes de primera mano, es decir, analizar y ubicar en otros archivos, tanto las películas, como los impresos derivados de su promoción - stills, lobby cards, carteles - , con tal suerte que, en la Filmoteca de la UNAM, encontramos un lobby card de la película El viaje LSD, también llamada Un largo viaje hacia la muerte, escrita y dirigida por José María Fernández Unsaín en 1967; un “melodrama psiquiátrico", como lo llama García Riera (1993: 252), en el cual se abordan las posibilidades terapéuticas del LSD. En la 
imagen, "Eva" (Fanny Cano) aparece atada a una rudimentaria camilla (como las que antiguamente se utilizaban en hopsitales psiquiátricos para dar electrochoques), ante la mirada de "Juan" (Miguel Ángel Álvarez). Localizamos también un still, en el que la actriz se oculta tras una gran escultura teniendo como fondo la misma camilla.

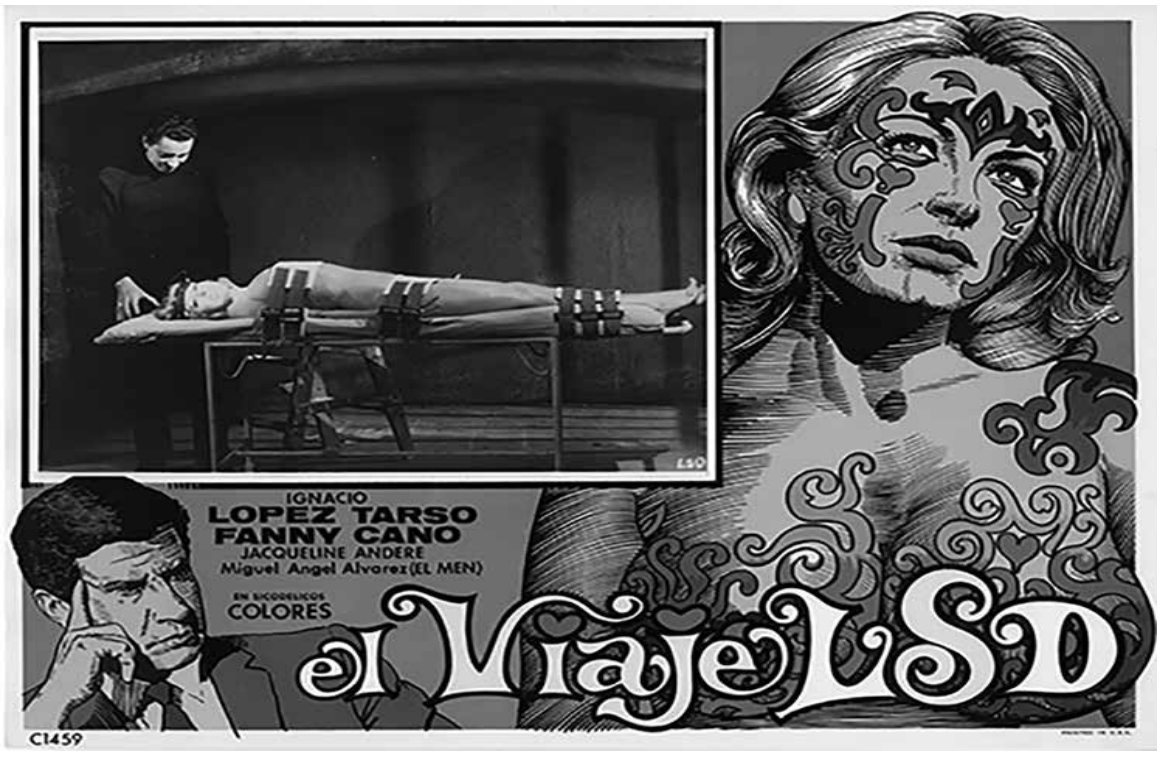

Ambas imágenes coinciden con el boceto aquí publicado, el cual muestra algunas características que le dieron fama a Fontanals: expresión, síntesis y propiedad en el diseño de ambientes, como el de este set construido en un foro de los Estudios Churubusco.

A modo de conclusión, podemos afirmar que si para la creación de un espacio fílmico se sigue "un proceso creativo, mental primero, resolutivo después, mediante su representación gráfica, artística y técnica, y finalmente otro más de concreción física" (Sanderson y Gorostiza 2010: 16), los apuntes y dibujos preparatorios eran - y siguen siendoimportantes en la realización de una película. De ahí la importancia de su identificación y conservación para el estudio de la escenografía, un tema por demás relegado en la historiografía del cine mexicano. 


\section{Bibliografía}

FonTANALS, Manuel (1946). "Conozca el cine por dentro. La escenografía", Novelas de la pantalla, noviembre, México: Editorial Serna, 16-18.

GARCía RIERA, Emilio (1993). Historia documental del cine mexicano. México: Universidad de Guadalajara, Imcine, Gobierno de Jalisco, Conaculta, tomo 13.

LozAno, Elisa (2014). Manuel Fontanals, escenógrafo del cine mexicano. México: Filmoteca de la UNAM, Dirección General de Publicaciones y Fomento Editorial, Difusión Cultural, Agrasánchez Film Archive.

Peralta Gilabert, Rosa (2007). Manuel Fontanals, escenógrafo: teatro, cine y exilio. Madrid: Fundamentos.

SANDERSON, John D. y Jorge Gorostiza (coords.) (2010). Constructores de ilusiones. La dirección artística cinematográfica en España. Valencia: Generalitat Valenciana, Filmoteca, IVAC.

\section{Agradecimientos}

La autora agradece a Leticia Fontanals Subervielle permitir la reproducción del boceto, el cual forma parte de su colección, donde conserva, además, otros documentos de su padre - fotografías, dibujos y planos arquitectónicos-; a Roberto Fiesco, el préstamo de materiales hemerográficos de su archivo, y al doctor Ignacio del Cueto Ruiz Funes, su interés en difundir la obra de Manuel Fontanals. 